\title{
SEKOLAH ISLAM TERPADU DALAM SEJARAH PENDIDIKAN ISLAM DI INDONESIA
}

\section{ISLAMIC SCHOOL INTEGRATED IN ISLAMIC EDUCATION HISTORY IN INDONESIA}

\author{
Ahmadi Lubis \\ Program Pasca Sarjana Universitas Islam Indonesia Yogyakarta \\ Jln. Demangan Baru No 24. Yogyakarta \\ E-mail : abiazka80@gmail.com.
}

Naskah diterima 17 Agustus 2018, diterima setelah perbaikan 22 November 2018, disetujui untuk dicetak 28 November 2018

\begin{abstract}
Abstrak
Kehadiran Sekolah Islam Terpadu dengan kurikulum integrasinya merupakan fenomena baru bentuk sistem pendidikan islam di Indonesia. Sampai akhir tahun 70-an sistem pendidikan Indonesia masih memiliki corak dikotomik. Seiring bergulirnya Reformasi di tahun 80- an ada upaya dari sebagai kalangan mencoba keluar dari sistem yang ada dengan gagasan Sekolah Islam Terpadu. Penelitian ini di fokuskan dalam rangka mengungkap bagaimana kehadiran Sekolah Islam Terpadu dalam sejarah pendidikan islam di Indonesia. Penelitian ini bersifat kualitatif dengan pendekatan diskriptif. Hasil dari penelitian ini diharapkan bermanfaat bagi siapa saja yang ingin mengetahui kehadiran Sekolah Islam Terpadu dalam sejarah pendidikan islam di Indonesia. Penelitian ini menemukan bahwa kehadiran Sekolah Islam Terpadu, dengan segala macam ragamnya, dalam sejarah pendidikan islam di Indonesia ini diprakarsai para aktifis pergerakan islam yang gelisah akan hasil lulusan sekolah di Indonesia. Dimana hasil lulusannya tidak memiliki daya tahan yang kokoh terhadap arus dan virus globalisasi, disebabkan sistem pendidikan sekolah di Indonesia bersifat dikotomik, mengusai ilmu-ilmu duniawi tapi tidak memiliki semangat keagamaan yang kuat, rentan dengan pengaruh virus globalisasi, jauh dari nilai-nilai Islami. Kondisi ini dirasakan kurang baik bagi masa depan generasi muslim Indonesia. Maka, alternatif dan solusinya perlu melakukan rekonstruksi ulang sistem pendidikan yang ada dengan menggunakan sistem pendidikan Islam terpadu. Meskipun demikian, konsep terpadu ini sudah ada sebelumnya. Jauh sebelum gagasan sekolah islam dengan slogan terpadu ini muncul sudah ada Adabiyah school, Diniyah school, Diniyah Putri dan Normal Islam di Sumatra Barat, dan pembaharuan pendidikan Islam Muhammadiyah di Yogyakarta, dll. Sekolah-Sekolah ini menerapakan konsep terpadu dalam aktifitas pendidikannya, seperti halnya Sekolah Islam Terpadu yang menjadi "trend baru" saat ini di Indonesia, khususnya diwilayah perkotaan dimana sekolah-sekolah ini didirikan, keberadaanya saat ini telah tersebar diseluruh Indonesia.
\end{abstract}

Keyword : Sekolah Islam Terpadu, Sejarah, Pendidikan Islam, Indonesia 


\begin{abstract}
The presence of Islamic school curriculum with integrated is a new phenomenon in the form of a system of Islamic education in Indonesia. Until the end of the year 70-s Indonesia's education system still has the marks of dichotomic. Just as Reform in 80-s there have been attempts from being among the try out of the existing system with the idea of an integrated Islamic school. The study on the target in order to uncover how the presence of Integrated Islamic school in the history of Islamic education in Indonesia. This research was qualitative in nature with description approach. The results of this research are expected to be of benefit to anyone who wants to know the presence of Integrated Islamic school in the history of Islamic education in Indonesia. The study found that the presence of Integrated Islamic school, with all sorts of exciting tours, in the history of Islamic education in Indonesia was initiated the Islamic movement activists nervous will the results of the graduate school in Indonesia. Where the results of the graduates do not have rock solid durability against the current virus, caused by globalization and the system of school education in Indonesia are dichotomic, colonised worldly sciences but did not have a strong religious zeal, vulnerable by the influence of virus globalization, far from Islamic values. This condition is felt less good for future generations of muslim's Indonesia. Thus, alternatives and solutions need to do reconstruction system of education there is by using Islamic education system. Nevertheless, the concept of this integration. Long before the idea of Islamic schools this integrated with the slogan appeared there was already a Adabiyah school, Diniyah school, Normal and Diniyah Putri Islam in West Sumatra, reformer and Islamic education in Muhammadiyah in Yogyakarta, etc. These schools are integrated in the concept of using educational activities, as well as Integrated Islamic school which became the "new trend" today in Indonesia, particularly the relic in cyitized where these schools are established, the current occurrence spread all over Indonesia.
\end{abstract}

Keywords: Integrated Islamic School, History, Islamic Education, Indonesia

\title{
PENDAHULUAN
}

Sejarah Pendidikan Islam di Indonesia mengalami dinamika pasang surut. Hal ini akibat kebijakan yang diambil pemerintah dalam mengatur regulasi sistem pendidikan nasional. Sampai akhir tahun 70-an sistem pendidikan di Indonesia masih memiliki corak yang sangat kental dengan sistem dikotomiknya, bahkan hingga saat ini dalam kadar tertentu. Seiring bergulirnya masa reformasi di tahun 80-an, ada upaya dari sebagian kalangan umat Islam mencoba keluar dari sistem yang ada dengan menggagas konsep pendidikan islam model terpadu.

Dalam sejarah pendidikan islam, sistem pendidikannya berlandaskan pada nilai-nilai islam dengan krakteristik yang khas. Filosofisnya mengacu pada nilai-nilai tauhid. Semua sistem pendidikannya mulai dari tujuan, kurikulum, dan lain-lainnya, harus berdasarkan pada prinsip ini. Sistem pendidikan yang memadukan seluruh aspek pendidikan dalam satu tujuan yang utuh, yaitu dalam rangka mengabdi kepada Allah SWT dan menjadi khalifah (pengelola dan pemakmur) bumi ini. Pikiran tersebutlah yang menjadi cikal bakal lahirnya Sekolah Islam Terpadu (SIT) di Indonesia. Pikiran yang dilandasi visi misi hidup seorang muslim, Majid Irsan al-Kilani mengatakan, konsep dasar filsafat pendidikan Islam itu didasarkan pada hubungan antara Kholiq (Tuhan) dengan manusia, hubungan manusia dengan alam semesta, hubungan manusia dengan manusia, hubungan manusia dengan kehidupan, dan hubungan manusia dengan alam akhirat.(Majid Irsan Al-Kilani, 1987: 75). 
Konsep dasar pendidikan Islam sebagaimana yang disampaikan al-Kilani tersebut tentunya akan berdampak pada sistem pendidikan islam secara keseluruhan. Sebagaimana menurut Abd. Halim Seabahar, bahwa sistem pendidikan islam harus dilihat dan dimaknai berdasarkan empat aspek yaitu: pendidikan islam sebagai materi, sebagai institusi, sebagai budaya dan aktivitas, dan sebagai sistem. (Abd. Halim Seabahar, 2013;1-5)

Pendidikan islam sebagai materi, berarti pendidikan yang mengajarkan ajaran Agama Islam. Pendidikan islam dalam pengertian kultur atau aktivitas berarti kultur atau nilai-nilai keislaman dan aktifitas yang tumbuh dan berkembang yang berpengaruh pada iklim pendidikan, seperti budaya, citra pendidikan islami, performance institusi pendidikan islami, dan aktifitas pendidikan Islami. Pendidikan islam sebagai sistem adalah semua komponen-komponennya, mulai dari dasar, filsafat, tujuan, prinsip, metode, evaluasi, kurikulum, dan sebagainya selalu mengacu pada ajaran normatif (alQuran-Hadits), artinya teori-teori pendidikan berlandaskan pada ajaran normatif. Pendidikan islam sebagai institusi berarti lembaga-lembaga yang didirikan umat Islam sebagai sarana mendidik anakanaknya, yang modelnya saat ini sangat pariatif, namun secara garis besar dapat dikategorikan menjadi empat institusi, yaitu pondok pesentren, madrasah, sekolah umum dan sekolah islam. (Abd. Halim Seabahar, 2013;1-5). Lembaga-lembaga yang dimaksud bukan berarti bangunan-bangungan, tetapi segala bentuk kegiatan yang di dalamnya mengandung nilai-nilai atau atauran-atauran. (Abuddin Nata, 2012: 190).

Dalam dasawarsa terakhir ini, terlihat fenomena berbeda yang menggembirakan sekaligus menggairahkan perkembangan pendidikan Islam di Indonesia. Hal ini terlihat tumbuhnya lembagaIembaga pendidikan Islam model terpadu dibeberapa kota besar di Indonesia, mulai dari jenjang pendidikan tingkat Taman Kanak-kanak, Sekolah Dasar, SLTP serta SMU. Kenyataan ini mengundang simpati umat Islam yang memandangnya sebagai bentuk modernisasi pendidikan Islam, sekalipun terkadang memunculkan adanya sikap pro dan kontra, terutama menyangkut soal sistem dan biaya pendidikan yang cukup tinggi. Menurut Imam Moedjion, modernisasi pendidikan Islam dilihat dari perspektif perkembangan kebudayaan dan peradaban manusia merupakan suatu keniscayaan. Hal ini menurutnya berdasarkan pada kenyataan bahwa sistem dan kelembagaan pendidikan konvensionaltradisional, sulit untuk dipertahankan sepanjang masa tanpa mengantisipasi dan merespon dinamika sosial serta tuntutan masyarakat. Keadaan seperti ini jika berlangsung terlalu lama, dalam jangka panjang akan menghadapi kesulitan untuk dapat survive ditengah modernitas tanpa upaya modernisasi diri yang selaras dengan perkembangan zaman, sekaligus kebutuhan dalam mewujudkan tatanan baru yang lebih beradab.(Imam Moedjiono : 2002: 78).

Menurut Kurninengsih, modernisasi lembaga-lembaga pendidikan islam di Indonesia dimulai pada tahun 1970-an, ketika Menteri Agama dipimpin Mukti Ali mengenalkan standardisasi sistem pendidikan madrasah melalui kerjasama antara 3 kementerian yakni Menteri Agama, Menteri Pendidikan dan Kebudayaan, dan Menteri dalam Negeri. Modernisasi tersebut diperkuat oleh Undangundang Sistem Pendidikan Nasional No. 2/1989, yang menyatakan bahwa madrasah merupakan bagian dari Sistem Pendidikan Nasional. Bahkan pemerintah telah memperkuat posisi madrasah dengan mengeluarkan Undang-undang Sistem Pendidikan Nasional No. 20 tahun 2003 yang menyatakan bahwa madrasah setara dengan sekolah umum. Namun demikian, hingga saat ini madrasah masih tetap menjadi lembaga pendidikan kelas dua, dalam pandangan masyarakat secara umum dan juga di 
kalangan pengambil kebijakan, meskipun seharusnya ini tak boleh ada, tapi faka lapangannya demikian. (Kurnianengsih: $2015: 79$ ).

Imam Moediono dengan mengutip Azra mengatakan, bahwa era Globalisasi dewasa ini dan dimasa datang sedang dan akan mempengaruhi perkembangan sosial masyarakat muslim Indonesia umumnya atau pendidikan islam khususnya. Menurutnya, umat yang hidup ditengah pusaran modernisme, suka tidak suka akan terimbas alur pikir dan pola pikir moderen, setidak-tidaknya akan terkena "radiasi' kultur modren yang serba cepat, sistematis, praktis, efektif dan efisien. (Imam Moedliono, 2002:78). Artinya umat Islam perlu dan harus menata sistem pendidikannya agar dapat mengimbangi laju era modernitas yang di picu Globalisasi, jika tidak, maka anak-anak muslim, khususnya kalangan remaja akan menghadapi keterbelahan identitasnya sebagai muslim dan sebagai makhluk modernis. Munculnya pendidikan islam model terpadu diawal tahun 80-an, menandai era adanya perubahan yang cukup menarik tentang trend pendidikan islam di Indonesia.

Dari fakta-fakta yang disebutkan tersebut memunculkan pertanyaan bagi peneliti, yaitu : Bagaimanakah kehadiran Sekolah Islam Terpadu dalam sejarah pendidikan Islam di Indonesia?. Apa yang melatar belakanginya? Bagaimana pandangan Islam terhadap pendidikan? Bagaimana konsep Pendidikan Sekolah Islam Terpadu sehingga ia menjadi alternatif pendidikan islam di Indonesia?. Dan masih banyak pertanyaan-pertanyaan lainnya.

Tulisan ini bertujuan mencari dan menemukan jawaban atas pertanyaan-pertanyaan tersebut, berdasarkan pada pemikiran bahwa Sekolah Islam Terpadu menjadi trend baru pendidikan islam di Indonesia, digemari masyarakat muslim perkotaan, meskipun dengan biaya yang cukup mahal. Dapat dipastikan ada sesuatu yang menjadi daya tarik bagi masyarakat memilih sekolah dengan sistem full day tersebut.

\section{METODOLOGI PENELITIAN}

Penelitian sejarah pendidikan islam model Sekolah Islam Terpadu di Indonesia merupakan penelitian sejarah dan perkembangan pendidikan islam di Indonesia. Meneliti sejarah pendidikan Islam terpadu di Indonesia sangat penting dilakukan, mengingat sistem yang digunakan sekolah ini berbeda dengan sistem sekolah pada umumnya.

Penelitian sejarah pendidikan Islam dapat dilakukan dengan dua pendekatan, yaitu pendekatan diskriptif dan pendekatan kompratif. (Ramayulis, 2012: 6.) Penelitian ini bersifat kualitatif dengan mengkaji sumber-sumber yang relevan dengan menggunakan metode analisis deskriptif, yaitu dengan mengungkap kehadiran sekolah Islam Terpadu dalam sejarah pendidikan islam di Indonesia melalui kajian perpustakaan, dengan cara mengumpulkan, mengklasifikasi, menganalisis data-data dari berbagai sumber yang relevan dengan cara pengamatan atau observasi.

Sumber utama dalam penelitian ini buku Standar Mutu Sekolah Islam Terpadu yang disusun tim penyusun dan pengurus Jaringan Sekolah Islam Terpadu Indonesia, diterbitkan pada tahun 2014. Didukung sumber lainnya berupa buku, jurnal, yang relevan dengan penelitian ini. Ditambah pengalaman penulis yang terlibat langsung lebih kurang 10 tahun dalam mengelola Sekolah Islam Terpadu. 


\section{PEMBAHASAN}

\section{Sekilas Perkembangan Sejarah Pendidikan Islam Di Indonesia.}

Sejarah pendidikan Islam di Indonesia mengalami priodeisasi yang sangat panjang dan dinamis, diawali dengan masuknya islam hingga saat ini. Sejarah pendidikan Islam di Indonesia mengalami dinamika pasang surut dan penuh tantangan. Ramayulis menulis dengan konperhensif tentang sejarah pendidikan islam di Indonesia, dalam bukunya "Sejarah Pendidikan Islam" ia membagi pase perkembangan pendidikan islam di Indonesia pada tiga priodeisasi. Yaitu : a. priode awal masuknya Islam ke Indonesia. b. priode masa kolonial (penjajahan Belanda dan Jepang). c. Priode Pembaharuan pendidikan Islam. (Ramayulis, 2012: 211-425).

Dari ketiga priode ini dapat dikatakan bahwa pendidikan islam di Indonesia ini hanya ada tiga ketegori model pendidikan, yaitu; pesantren, sekolah dan madrasah, dengan ciri masing masing yang bercorak dikotomik, bukan terpadu, terutama model sekolah dan pesantren.

KarelA. Steenbrink, sekolah merupakan kebijakan politik pendidikan yang dirancang Belanda, dan diteruskan hingga saat ini. Sementara pesantren merupakan lembaga pendidikan Islam tradisional dengan pengajaran kitab-kitab kuning yang dipinpin para kiyai, dan merupakan ciri khas pendidikan Islam awal yang ada di Indonesia dengan segala varian dan corak ragamnya. Meskipun menurut Karel A. Steenbrink, duapuluh tahun terakhir banyak pesantren telah mengadopsi sistem madrasah dan memasukkan mata pelajaran umum dalam sistem pendidikannya. Sistem madrasah diperkenalkan untuk menjembatani kesenjangan antara pesantren dan sekolah yang pada akhirnya melahirkan dualisme dalam sistem pendidikan nasional. Dengan memberikan penekanan pada mata pelajaran agama, pesantren seringkali dianggap tidak mampu merespons kemajuan dan tuntutan zaman. (Karel A. Steenbrink:1986:167)

Dari paparan Steenbrik diatas ditemukan adanya pergeseran model pendidikan dipesantren yang mengembangkan sistemnya menjadi madrasah, meskipun sistem pesantren tetap dipertahankan, artinya pesantren mengajarkan ilmu pengetahuan umum dalam kurikulumnya. Berbeda dengan model sekolah yang sejak awal kurang memberikan perhatian pada pendidikan Agama Islam.

Pada awal mulanya, Pendidikan Agama Islam tidak masuk dalam struktur kurikulum pendidikan disekolah, sebab agama dianggap privasi masing-masing individu, bahkan terkesan diabaikan. Perjuangan para tokoh-tokoh Pendidikan islam dalam upaya memasukkan Pendidikan Agama Islam (PAI) menjadi pelajaran wajib disekolah baru terealisasi pada tahun 1989 dengan dikeluarkannya Undang-Undang Sisdiknas no 2 Tahun 1989 dan diperkuat di tahun 2003 didalam Undang-Undang Sistem Pendidikan Nasional No 20 Tahun 2003. Meskipun demikian, Pendidikan Agama Islam kurang mendapat porsi yang cukup dalam mewujudkan tujuan pendidikan nasional yang dicita-citakan, yaitu mewujudkan manusia Indonesia yang bertaqwa dan berakhlak mulia.

Kurangnya perhatian terhadap Pendidikan Agama Islam disekolah (dikotomik) merupakan salah satu sebab munjulnya ide atau gagasan munculnya sistem Sekolah Islam Terpadu.

\section{Pandangan Islam Terhadap Pendidikan}

Islam memandang dan menempatkan pendidikan ditempat dan dalam posisi yang sangat strategis dalam membangun sebuah peradaban, peradaban yang memberi rahmat (kasih sayang) bagi seluruh alam semesta, dan ini sesuai dengan visi dan misi Islam sebagai rahmat dan anugrah bagi alam semesta. Bukan pendidikan yang melahirkan peradaban yang menomarsatukan materi, peradaban yang 
melahirkan penguasaan pada kekayaan dan harta benda, bukan peradaban yang bengis dan arogan. Pendidikan yang tidak memisahkan antara kebutuhan kehidupan dunia dan kebutuhan kehidupan akhirat. Tidak memfokuskan pada satu aspek saja dalam kehidupan manusia. Islam memandang bahwa pendidikan harus di integrasikan antara ilmu dan agama, antara dunia dengan akhirat menjadi satu keseimbangan yang harmoni dan saling mendukung, bukan saling menafikan. Pendidikan dilakukan untuk mempersipkan manusia agar memiliki kesadaran, kemampuan, dan tanggung jawab untuk menjalankan misi ke-khilafahan sebagai amanah dari Allah SWT.(Tim Mutu JSIT Indonesia: 2014:1).

Para ahli memiliki pandangan berbeda terhadap makna pendidikan, perbedaan ini sudah barang tentu dilatar belakangi sudut pandang yang berbeda terhadap objek pendidikan tersebut. Perbedaan ini lebih didasarkan pada pandangan masing-masing ahli tentang hakikat manusia, dan kehidupan ini, ada yang memandang pendidikan itu dari sisi kebutuhan akal manusia itu saja, ada yang memandang kebutuhan fisiknya, ada yang memandang kebutuhan nafs, pisikisnya saja. Ada juga yang memandang dari sisi hasil dan realitas dari proses pendidikan tersebut, yaitu pekerjaan dimana pendidikan diarahkan untuk meningkatkan status sosial, mendapatkan pekerjaan yang layak. Ada yang melihat dari sudut pandang nilai-nilai moral dan islam. Sehingga dengan demikian dalam mengonsep atau mendefenisakan pendidikan pun disesuaikan dengan tujuan yang akan direalisasikan tersebut.

Zainab Basyarah Yusuf, dalam tesisnya yang berjudul “ Asaaliib al-tarbiyah fi al-Quran alKarim", mengungkapkan pandangn para ahli tentang pendidikan ini berdasarkan sudut pandang yang berbeda-beda tersebut.

Menurut Zainab, ada yang mendefenisikan pendidikan dari sudut pandang pengembangan potensi akal, jasmani dan jiwa sebagai berikut :

\section{هي تنمية الوظائف الجسمية والعقلية والخلقية حتى تبلغ كمالها عن طريق التدريب والتثقيف.}

Pendidikan dalam upaya mengembangkan, mendayagunakan potensi dan fungsi-fungsi jasamaniyah, aqliyah dan khuluqiyah sampai mencapai tingkat kesempurnaan dengan cara latihan-latihan dan pembudayaan. (Zainab Basyarah Yusuf, 1431, :11-12)

Pendidikan dari sudut pandang para tokoh-tokoh pendidikan didefenisakannya sebagai berikut

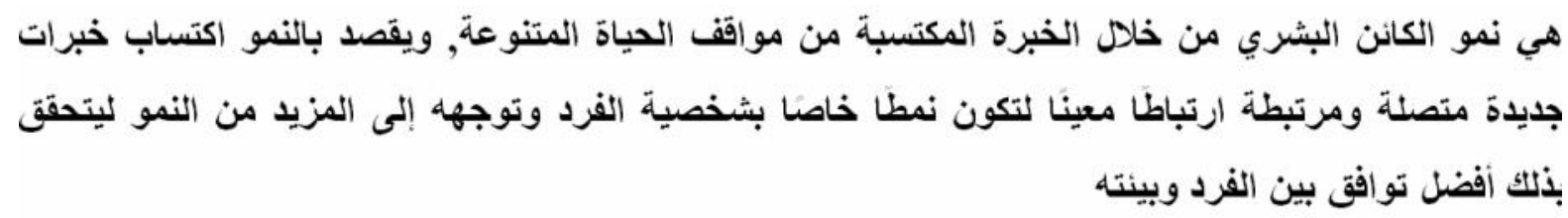

Pendidikan adalah upaya mengembangan potensi manusia dengan cara-cara pemberian pengalaman yang dihasilkan dari kondisi-kondisi kehidupan yang beragam dan berwarnawarni, dengan maksud bahwa potensi tersebut menghasilkan pengalaman baru yang singkron dan terkolerasi secara kuat dan bermakna agar menjadi model yang khas dengan karakter individu-individu tersebut dan dalam rangka mengarahkan agar potensi itu terus bertambah dalam upaya mewujudkan hubungan yang harmoni antara individu dengan kondisi lingkungannya. (Zainab Basyarah Yusuf, 1431, :11-12)

Menurut Zainab, ada yang mendefenisikan pendidikan dalam pandangan Islam sebagai berikut:

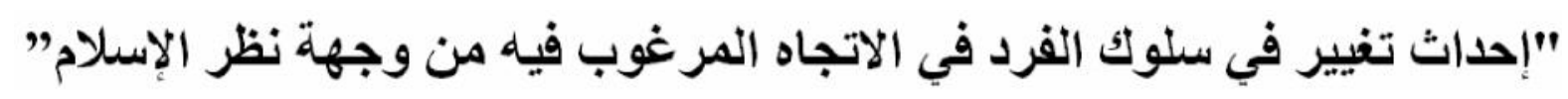


Pendidikan adalah usaha yang dilakukan dalam rangka melakukan perubahan terhadap prilaku setiap orang kearah yang diharapakan islam (Zainab Basyarah Yusuf, 1431, :11-12)

Dari pandangan-pandanagn tersebut Zainab mengemukan defenisi atau konsep pendidikan yang lebih konferhensip, yaitu :

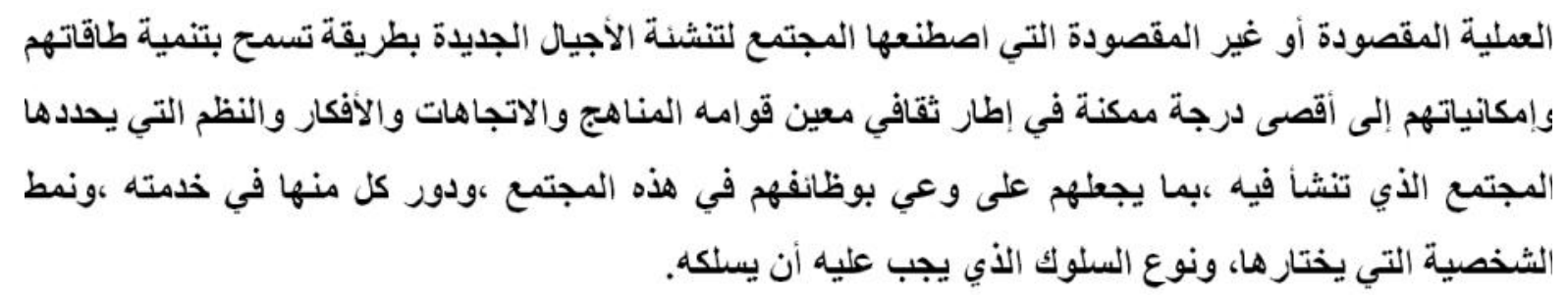

Pendidikan adalah usaha yang direncanakan ataupun tidak direncanakan yang dilakukan oleh masyarakat dalam upaya melahirkan generasi baru dengan cara yang dapat mengembangkan seluruh kemampuan dan potensinya hingga mencapai tingkat tertentu yang didukung dari segi keterampilan tertentu yang dapat mengarahkannya, berupa kurikulum, arahan-arahan, pikiran-pikiran dan aturan-aturan yang dikonsep oleh masyarakat tersebut dari budaya yang tumbuh dari dalam kehidupan bermasyarakat, peran-peran yang menyertainya, krakter atau model yang mereka pilih yang harus dijalankan sebagi satu prilaku kehidupan. (Zainab Basyarah Yusuf, 1431, :11-12)

Dari semua defenisi atau konsep tentang pendidikan yang disampaikan tersebut pada dasarnya pendidikan itu dalam rangka upaya mengembangkan seluruh potensi atau kemampuan yang dimiliki manusia agar mampu menciptakan kehidupan yang lebih beradab dan lebih bermakna, artinya pendidikan untuk kemaslahatan, peradaban manusia di alam semesta ini.

Dalam pandangan Majid Irsan al-Kilani, konsep dasar filsafat pendidikan dalam Islam itu didasarkan pada hubungan antara Kholiq (Tuhan) dengan manusia, hubungan manusia dengan alam semesta, hubungan manusia dengan manusia, hubungan manusia dengan kehidupan, dan hubungan manusia dengan alam akhirat.( Majid Irsan Al-Kilani, 1987:75).

Konsep dasar ini tentunya akan berdampak pada tujuan, kurikulum, materi ajar dan bahkan metode dan strategi yang terapkan dalam pendidikkan islam. Oleh sebab itu menurut Abuddin Nata konsep pendidikan dalam islam itu sangat variatif, bahkan sampai tiga belas konsep dan kesemuannnya merupakan satu kesatuan dalam pendidikan islam, artinya satu sama lainnya saling terhubung dan terkait. Menurut Abuddin Nata memahami dan melaksankan semua konsep ini akan membuat pemahaman dan pengetahuan tentang pendidikan semakin utuh dan komperhensif. (Abuddin Nata, 2010: 27-28).

Ketiga belas konsep pendidikan Islam yang disampaikan Abuddin Nata tersebut dapat dilihat dalam tabel dibawah ini.

Lihat Uraian singkatnya dalam tabel berikut ini: 


\begin{tabular}{|c|c|c|c|}
\hline tarbiyah & $\begin{array}{l}\text { Pendidikan,pengembangan } \\
\text { Perintah,pengajaran,pembi } \\
\text { naan } \\
\text { keperibadian,memberi } \\
\text { makan, menumbuhkan. }\end{array}$ & $\begin{array}{l}\text { wa'adz / } \\
\text { mau'idzah }\end{array}$ & $\begin{array}{l}\text { Mengajar, kata hati, } \\
\text { suara hati, hati } \\
\text { nurani,memperingatkan, } \\
\text { mendesak, }\end{array}$ \\
\hline ta'lim & $\begin{array}{l}\text { Pemberitahuan tentang } \\
\text { sesuatu, nasehat, } \\
\text { perintah,pengarahan,penga } \\
\text { jaran,pelatihan } \\
\text { Pembelajaran,pendidikan, } \\
\text { pekerjaan magang,belajar } \\
\text { keahlian. }\end{array}$ & riyadhah & $\begin{array}{l}\text { Menjinakkan,mendobra } \\
\text { k,latihan, } \\
\text { menenangkan,mempera } \\
\text { gakan,melatih, mengatur }\end{array}$ \\
\hline ta'dib & $\begin{array}{l}\text { Pendidikan, } \\
\text { disiplin,patuh,tunduk pada } \\
\text { aturan,peringatan dan } \\
\text { hukuman,penyucian, } \\
\text { beradab, tata karma, } \\
\text { akhlak, moral,etika,budi } \\
\text { pekerti. }\end{array}$ & tazkiyah & $\begin{array}{l}\text { Pemurnian,pembersihan } \\
\text {,kesucian,pengumuman, } \\
\text { pernyataan,ketulusan } \\
\text { hati, kejujuran, } \\
\text { kesaksian,catatan yang } \\
\text { dapat dipercaya. }\end{array}$ \\
\hline tahzib & $\begin{array}{l}\text { Pendidikan } \\
\text { penyucian diri, terdidik, } \\
\text { terpelihara, adab, sopan } \\
\text { santun }\end{array}$ & Talqin & $\begin{array}{l}\text { Perintah,anjuran,pengar } \\
\text { ahan,mendikte,inspirasi, } \\
\text { sindiran,dorongan,penga } \\
\text { jaran }\end{array}$ \\
\hline tadris & $\begin{array}{l}\text { Pengajaran,perintah,kuliah } \\
\text {,pengaruhnya membekas, } \\
\text { menimbulkan perubahan. }\end{array}$ & tafaqquh & $\begin{array}{l}\text { Mengerti, memahami, } \\
\text { menghubungkan yang } \\
\text { abstrak ke konkret. }\end{array}$ \\
\hline tabyin & $\begin{array}{l}\text { Mengemukakan,mempertu } \\
\text { njukkan,penjelasan,pengga } \\
\text { mbaran. }\end{array}$ & tazkirah & $\begin{array}{l}\text { Peringatan, reminding, } \\
\text { mengulang } \\
\text { kembali,memproduksi,p } \\
\text { enyerbukan,peringatan } \\
\text { bersifat umum, }\end{array}$ \\
\hline irsyad & \multicolumn{3}{|c|}{$\begin{array}{l}\text { Membimbing, menunjukkan jalan, perhatian, bimbingan rohani, } \\
\text { perintah, pengarahan, pemeberitahuan, nasehat. }\end{array}$} \\
\hline
\end{tabular}


Konsep-konsep pendidikan ini yang disampaikan Abudddin Nata tersebut merupakan aspek yang harus di penuhi dan menjadi kebutuhan individu-ndividu peserta didik. Bahkan dibutuhkan dalam mendidik masyarat yang lebih luas.

Dari uraian diatas sangatlah jelas bahwa pendidikan Islam itu memiliki konsep yang khas yang di dasarkan pada filsafat tauhid, dimana manusia dengan potensi yang dimilikinya tidak bisa lepas dari hubungannya kepada Tuhannya, berupa ibadah dan pengabdian, hubungannya dengan manusia berupa berbuat baik dan adil, hubungannnya dengan alam berupa ekplorasi, pemanfaatan dan pendayagunaan, bukan penguasaan dan ekploitasi, hubungannya degan kehidupan dunia berupa ujian dan cobaan, hubungannya dengan kehidupan akhirat berupa pembalasan dan pertanggungjawaban. (Majid Irsan Al-Kilani, 1998: 1-159).

Pandangan ini menunjukkan bahwa pendidikan islam itu bersifat terpadu, tanpa memisahmisahkan antar akal dan wahyu, antara dunia dengan akhirat, antara ilmu dengan agama. Dengan demikan tidak ada konsep dikotomik pendidikan dalam pandangan Islam. Pandangan al-Kilani ini juga menegaskan bahwa pendidikan islam itu tidak hanya bersifat antroposentris, (berorentasi pada kemanusiaannya) saja, juga tidak bersifat teosentiris (berorentasi ketuhanan) saja, tapi pendidikan dalam pandangan Islam itu bersifat teosentris-antroposentris plus ekosentris, yaitu pendidikan yang didasarkan pada nilai-nilai ilahiyah (ketuhanan/teosentris), insaniyah (kemanusiaan/antroposentris) dan alamiyah/ekosentis (alam semesta), dimana tujuan pendidikan islam itu dalam rangka menjaga hubungan baik dengan Tuhan, Allah SWT, mengatur hubungan dengan manusia, berintraksi secara sosial, dan mengatur hubungan manusia dengan alam semesta ini.

\section{Prakarsa Awal Sekolah Islam Terpadu Di Indonesia}

Sekolah Islam dengan embel-embel terpadu merupakan pendatang baru dalam sejarah pendidikan islam di Indonesia. Meskipun tergolong baru, sekolah islam dengan slogan terpadu ini menunjukan eksistensi yang baik, dan saat ini menjadi trend bagi sebagian masyarakat muslim, khususnya diperkotaan, meskipun dengan biaya yang cukup mahal. Menurut Suyatno, dalam waktu yang relatif singkat, jumlah sekolah Islam terpadu telah mencapai \pm 10.000 sekolah diseluruh wilayah Indonesia. (Suyatno, 2013:361).

Fakta tersebut membuktikan adanya kepercayaan masyarakat muslim Indonesia atas sekolah-sekolah Islam dengan label terpadu tersebut, dan ini tentunya sangat membantu bagi pemerintah dalam mewujudkan manusia Indonesia yang cerdas dan bebas buta aksara, yang merupaka amanat Undang-Undang Dasar 1945, dalam rangka mengisi dan sekaligus mensyukuri kemerdekaan Indonesia.(Baca. Amanat Undang-Undang Dasar 1945).

Abuddin Nata menjelaskan, ketika Indonesia merdeka pada tahun 1945 dan bebarapa waktu setalah itu, pendidikan di Indonesia dalam keadaan dualistik atau dikotomik. Hal ini merupakan akibat dari pendidikan yang diwariskan Belanda yang mengajarkan ilmu-ilmu secara sekuler, disisi lain ada pendidikan pesantren yang hanya mengajarkan ilmu-ilmu agama yang bersumber dari kitab kuning yang ditulis para ulama pada abad klasik dan pertengahan, sebagian besar merujuk kepada paham Islam suni yang dibawa oleh para ulama yang pernah belajar di al-Haramain (Mekkah dan Madina).(Abuddin Nata, 2015: 3). 
Pada dekade akhir tahun 1980-an, Sekolah Islam dengan label terpadu mulai bermunculan di Indonesia. Konsep Pendidikan islam ini diprakarsai para aktivis dakwah kampus dari berbagai universitas negeri di Indonesia, hal ini cukup menarik, mengingat pendidikan Islam itu seharusnya lahir dari aktifis perguruan tinggi Agama Islam di Indonesia. Namun, faktanya bukan demikian. Munculnya pemuda-pemuda dari kampus non Agama Islam sebagai penggerak berdirinya sekolah islam terpadu di Indonesia merupakan tanda berubahnya pola pikir terhadap nilai-nilai Islam dilingkungan masyarakat muslim Indonesia. Kesadaran ini tentu tidak datang dengan begitu saja, pasti ada yang melatar belakanginya.

Jika kita kaji lebih jauh sejarah pendidikan islam di Indonesia, konsep pendidikan islam dengan model terpadu akan kita temukan ide dan gagasannya, meskipun tidak dengan label terpadu. Sistem pendidikan sekolah dengan memadukan pelajaran umum dan agama telah ada sebelumnya. Pada tahun 1909, Abdullah Ahmad telah mendirikan Adabiyah School di Sumatra Barat, meskipun pada awalnya sekolah ini berbentuk Madrasah, tapi pada akhirnya berubah menjadi sekolah, HIS. Konsep kurikulumnya pun sama dengan konsep Sekolah Islam Terpadu saat ini, yaitu integarasi. (Ramayulis : 2012: 302).

Selain Adabiyah School, ada juga yang menggunakan konsep yang sama, seperti Diniyah School, tahun 1915 di gagas Zainuddin Labai el-Yunus, Diniyah Putri, tahun 1923 digagas adik Zainuddin, yaitu Rahmah el-Yunusiyah, Normal Islam, tahun 1932 digagas Muhammad Yunus. Jauh sebelumnya, tepatnya tahun 1901, ada Jami'ah al khair di Jakarta yang mengagas pendidikan Islam model integarsi, dan Al-Irsyad pada tahun 1913 di Jakarta dan Surabaya. Dan pembaharuan pendidikan islam Muhammadiyah di Yogyakarta pada tahun 1925, serta pembahruan pendidikan islam Persatuan Islam di Bandung pada tahun 1923. (Ramayulis : 2012: 302-319).

Dengan demikan, konsep pendidikan islam terpadu atau integrasi antara mata pelajaran umum dengan agama, telah ada pemikiran dan contohnya di Indonesia sebelum kehadiran Sekolah Islam dengan slogan terpadunya tersebut, bisa jadi para pemikir dibelakang aktifis kampus tahun 80-an tersebut dipengaruhi pemikiran dan gagasan dari Abdullah Ahmad, elYunus dan Rahamh el-Yunusiyah, dllnya, meskipun ini perlu dilakukan kajian lebih lanjut.

Akan tetapi, konsep yang di gagas para pendiri Sekolah Islam Terpadu di Indonesia ini tidak hanya sekedar integrasi, dalam arti menyatukan antara mata pelajaran agama dan umum dalam satu sistem. Makna terpadu didalam slogan Sekolah Islam Terpadu tersebut bermakna Islamisai ilmu pengetahuan. (Tim Mutu JSIT Indonesia : 2014: 9). Konsep ini lebih mirip dengan konsep "Islamisasi Sains" Ismail al-Faruqi. Akan di jelaskan dalam bagian berikutnya tentang makna "Terpadu".

\section{Sebab- Sebab Munjulnya Gagasan Sekolah Islam Terpadu di Indonesia}

Adanya fakta dikotomi antara ilmu Agama Islam dan Ilmu umum di dalam sistem pendidikan sekolah di Indonesia, diyakini bukan satu-satunya alasan lahirnya ide atau gagasan mendidirikan sekolah Islam terpadu, tetapi juga di dasarkan pada faktor-faktor lainnya, seperti faktor ideologi atau pemikiran bahwa ajaran Islam itu bersifat syumuliyah (universal) dan mutakamiliyah (konperhensif). Artinya ada semangat yang mendorong untuk merealisasikan bahwa sekolah sebagai bentuk miniatur dari kehidupan masyarakat muslim. 
Dengan demikan, diharapkan para lulusan lembaga pendidikan Islam terpadu dapat dan mampu menciptakan dan mewujudkan lulusan pendidikan yang berkepribadian, bertaqwa dan berakhlak mulia, pribadi-pribadi yang syamil (utuh) secara akidah, pikiran dan kamil (sempurna) pada tindakan dengan bentuk akhlak dan pengamalan ajaran-ajaran dan nilai-nilai Islam secara menyeluruh ( $k a f f a h)$ dalam kehidupannya, sehingga mereka di harapkan menjadi model dan contoh bagi luluasan pendidikan sekolah yang mampu menjalankan nilai-nilai Islam layaknya lulusan pesantren.

Semangat merubah sistem pendidikan dikotomik-sekuler menjadi dorongan paling kuat dalam menggagas berdirinya pendidikan Islam terpadu di Indonesia. Hal ini disebabkan hasil lulusan model lembaga pendidikan yang ada saat itu diangggap tidak mampu menjawab tantangan dan kebutuhan zaman. Pendidikan sekolah umum hanya membekali siswanya tentang ilmu-ilmu umum, jauh dari nilainilai keislaman. Hasilnya, meskipun para siswa memiliki kemampuan penguasaan sains dan teknologi, mereka tidak memiliki basic pendidikan moral agama Islam yang kokoh sehingga dapat terjerumus ke dalam penyakit budaya modern, semisal; free seks (pergaulan bebas), penggunaan narkoba, kenakalan remaja, dan lain- lain. Sebaliknya, pendidikan Islam seperti pesantren hanya membekali siswa tentang ilmu-ilmu agama ansich, tidak mampu dan tidak mumpuni dalam penguasaan sains dan teknologi, meskipun dianggap memiliki pondasi moral agama islam yang cukup. Lulusannya dianggap tidak dapat eksis ditengah-tengah perkembangan zaman modern dengan model pendidikan islam seperti itu, apalagi jika di hubungkan dengan kesempatan lapangan kerja yang sangat kompetitip dizaman globalisasi ini.

Menurut para aktor Sekolah Islam Terpadu tersebut dibutuhkan mengubah pendidikan dikotomik itu, sudah tidak layak dipertahankan, apalagi ada kesan bahwa filosofis sekolah dikotomik tersebut bersumber dari pemikiran sekulerisme. Oleh sebab itu, diperlukan formula baru dengan menggagas dan mengagali model pendidikan Islam terpadu yang telah ada historisnya dalam sejarah pendidikan Islam di Indonesia. Ditambah tujuan pendidikan islam yang di harapkan seharusnya mengaju pada hal-hal beriku ini :

1. Para lulusan pendidikan sekolah Islam diarahkan bukan hanya untuk mementingkan kehidupan pragmatis, hedonis, dan materialis semata.

2. Sosok manusia yang diharapkan sistem pendidikan kini dan mendatang adalah insan yang religius, berkepribadian, cerdas, kreatif, sehat, dan bermanfaat bagi masyarakat dan bangsa, sehingga mampu berfungsi sebagai hamba Allah dan khalifah di atas bumi.

3. Orientasi pendidikan adalah pembentukan manusia seutuhnya, bukan kompilasi dari seluruh aspek kehidupan (jasmani, emosi, pikir, sosial dan moral).

Oleh sebab itu, sistem pendidikan Islam yang paling efektif untuk memenuhi harapan tersebut adalah sistem pendidikan islam terpadu. Dengan demikian, munculnya gagasan sekolah Islam Terpadu di Indonesia lebih didorong dan merupakan respon atas ketidakpuasan terhadap sistem pendidikan nasional dikotomik yang dianggap tidak mampu menjawab kebutuhan dan tantangan zamannya, khususnya berhubungan dengan kemajuan ilmu pengetahuan dan teknologi yang dibarengi dengan nilai-nilai Islam. 
Wacana integrasi sains dan Islam meningkat seiring sejalan dengan tumbuh suburnya ideologi Islam yang sangat asertif $^{1}$ dalam mencoba mengimplementasikan berbagai visi-misi Islam dalam pendidikan, sosial, ekonomi, maupun politik. Hal ini tidaklah mengherankan karena para pendiri sekolah Islam terpadu secara umum memiliki semangat yang tinggi untuk meniru dan mengulangi kembali zaman keemasan Islam yang dianggap lebih murni, Islam ideal dimana kehidupan zaman sekarang harus didasarkan pada konsep pembentukan generasi tersebut, jika tidak, Islam hanya sebagai cita-cita saja, atau bahkan angan-angan saja.

Menurut Yudian wahyudi, seperti di kutif Kurnianengsih, fenomena munculnya Sekolah Islam Terpadu, merupkan bentuk kesadaran, setelah babak belur hampir tiga abad, barulah umat Islam, khususnya di Indonesia, mulai sampai pada pengertian kembali kepada al-Quran dan Sunnah. Kembali kepada al-Quran dan Sunnah bukan kutukisme, tetapi tauh îd al-'ulûm (atau kesatuan ilmu yang meliputi ayat quraniyah, ayat kauniyah, dan ayat insaniyah). Dengan semangat inilah lahirlah Sekolahsekolah Islam Terpadu di Indonesia. (Kurnianingsih, 2015: 80).

Selain dua faktor utama diatas, juga di yakini ada faktor lainnya, seperti faktor pemenuhan lapangan kerja, pemenuhan ekonomi (kasbul ma'isyah) para aktivis pergerakan islam tersebut, yang merasa tidak mendapat tempat dan kurang berkenan masuk menjadi pegawai negeri sipilmeskipun sebagian para pendirinya berlatar belakang pegawai negeri sipil, seperti dosen, guru dilembaga-lembaga pemerintahan. Dan sudah barang tentu hal ini membantu pemerintah dalam mengurangi angka pengangguran di tingkat sarjana.

\section{M akna "Terpadu" pada Sekolah Islam Terpadu di Indonesia}

Istilah "terpadu" saat ini menjadi trend bagi pendidikan Islam di Indonesia, meskipun jika diperhatikan trem ini tidak memiliki pemaknaan yang sama dalam penggunaannya. Kehadiran sekolah Islam terpadu membuat banyak kalangan menjadikannnya sebagi brand atau lambang dari sekolahnya. Ini artinya istilah "Islam terpadu" dianggap mampu memberikan keperjayaan kepada publik akan lembaga pendidikan "sekolah" yang dikelola ummat.

Istilah "Sekolah Islam Terpadu" menjadi viral dipublik saat sekolah-sekolah Islam dibawah JSIT Indonesia menjadikannya sebagai slogan sekolah mereka, dan dapat bersaing secara nasional dalam banyak aspek, baik dari sisi akademik mau pun non-akademik. Sekolah Islam Terpadu ini mulai menggeser nominasi sekolah-sekolah swasta lainnya, bahkan dapat menyaingi sekolah negeri.

Seperti dijelaskan sebelumnya, bahwa sekolah Islam terpadu merupakan antitesa dari ketidak puasan atas sistem sekolah nasional, yang menurut para penggagasnya kurang memberikan porsi yang cukup untuk pendidikan agama Islam. Namun, sayangnya menurut Suyatno, sekolah-sekolah Islam terpadu justru jadi paradoks, sebab pada dasarnya sekolah islam terpadu tidak bisa lepas dari sistem pendidikan nasional, hal ini menurutnya dapat diindikasikan dari berbagai faktor, diantaranya : 1) penggunaan nama sekolah; 2) adopsi kurikulum nasional; 3) penyesuaian sistem ujian, dan 4) sertifikasi guru oleh guru-guru sekolah Islam terpadu.(Suyatno, 2015: 2).

\footnotetext{
${ }^{1}$ Suatu kemampuan mengkomunikasi apa yang diinginka,dirasakan, dan dipikirkan kepada orang lain,namun tetap menjaga dan menghargai hak-hak serta perasan pihak lain tersebut.
} 
Aspek-aspek yang menjadi paradoks dalam pandangan Suyatno tersebut tidak punya alasan yang kuat, mengingat tempat dan waktu sekolah islam terpadu ada di Indonesia, dimana pendidikan di Indonesia secara regulasi bersifat sentralistik, dan hanya pada hal-hal tertentu saja yang bersifat desantralistik. Pengelolaan pendidikan sudah di atur dalam Peraturan Menteri Pendidikan Nasional. Dan dapat dimaklumi jika Sekolah Islam Terpadu mengadopsi dan mengikuti regulasi yang ada. Meskipun ada hal-hal yang sifatnya kreatif dari pengelola sekolah Islam terpadu tersebut.

Dalam buku Standarisasi Mutu Kekhasan Sekolah Islam Terpadu disebutkan bahwa kata terpadu lebih pada penguat (taukid) dari Islam Itu sendiri (Tim Mutu JSIT Indonesia : 2014:5). Oleh sebab itu, ada yang penilaian bahwa penggunaan label "Terpadu" sesungguhnya merupakan penggunaan yang bersifat pragmatis, untuk mengiformasikan kepada masyarakat bahwa sekolah ini berbeda dengan sekolah pada umumnya, disaat yang bersamaan sebagian masyarakat memandang sekolah secara umum kurang mampu merespon kebutuhan masyrakat muslim, sistem sekolah secara nasional dianggap kurang memuasakan sebagian masyarakat Islam. (Suyatno, 2015: 5).

Apa yang disebutkan Suyatno tersebut tidak sepenuhnya benar, sebab menurut penulis kata terpadu tesebut lebih pada penegasan bahwa sekolah ini di kelola dan di jalankan secara islami, profesional dan kredibel. Hal ini sesui dengn visi, misi dan strategi sekolah Islam terpadu tersebut. Dengan demikain dibutuhkan sekolah yang pengelolaan profesional dan kredibel, dalam posisi ini sekolah-sekolah Islam dengan label terpadunya mencoba menggagas sekolah-sekolah Islam yang kredibel tersebut, baik dari segi menajemannya maupun dari segi pelaksanaan pendidikannya, menajemen yang profesional, dan sarana prasarana yang modren. Disaat yang bersamaan memiliki ciri khas keIslaman yang memadai untuk menghadapi arus globalisasi yang hedonis. (Tim Mutu JSIT Indonseia :2014: 5-7).

Seiring dengan berkembangnya sekolah-sekolah Islam terpadu dibawah Jaringan Sekolah Islam Terpadu Indonesia, yang diperkirakan sudah hampir ada diseluruh provinsi dan kabupaten di Indonesia, membuat banyak kalangan untuk menjadikan simbol bagi lembaga pendidikannya. Sampai pada akhir-akhir ini, ditemukan slogan terpadu tersebut tidak hanya ada pada lembagalembaga pendidikan yang di kenal dengan istilah sekolah saja, melainkan juga ada yang berlabel Madrasah. Bahkan, bukan monopoli swasta melainkan juga ada yang negeri. Seperti dikutip dari Imam modjiono, yang mencontohkan Madrasah Ibtidaiyah Negeri I Malang, pada hakekatnya juga merupakan sekolah terpadu dan merupakan madrasah terbaik se Jawa Timur serta manjadi proyek percontohan atau sekolah model di Indonesia. (Imam Moedliono, 2002:70).

Dalam perkembangannnya, istilah "Islam terpadu" ini ada yang mengubahnya dengan nama lain, tentunya dengan tujuan yang bisa sama, tapi juga bisa berbeda, seperti Islam Integral, ada yang menggunakan terpadu saja, tanpa label kata "Islam" tapi dengan simbol lainnyanya, misalnya, terpadu al-Hikmah, Muhammadiyah Terpadu, dll.

Meskipun sama-sama menggunakan slogan terpadu, ada beberapa perbedaan pemaknaan istilah "terpadu" tersebut dikalangan penyelenggara pendidikan islam terpadu. Seperti dikutip dari Imam Moedjiono yang memuat beberapa sekolah dengan label terpadu, namun memiliki pemaknaan yang berbeda-beda. Misalnya, Sekolah Islam Terpadu Fajar Hidayat, memaknai istilah pendidikan terpadu dengan sistem pendidikan yang memadukan konsep pendidikan Islam integral dengan metode pendidikan modren. Sekolah Islam Terpadu Aulia memaknai istilah pendidikan terpadu dengan pendidikan yang memadukan kurikulum pendidikan dari pemerintah dengan pengajaran ke-Islaman 
yang dilakukan secara kreatif. Sedangkan SLTP Islam Terpadu Hidayatullah memaknai pendidikan terpadu dengan sistem pendidikan yang berupaya memadukan ranah afektif, kognitif dan psikomotor atau antara rumah, sekolah dan lingkungan, atau antara fisik dan akal, serta antara dunia dan akherat. (Imam Moedliono, 2002:75)

Lain halnya dengan sekolah Islam terpadu di Yogyakarta, seperti dikutip dari Suyatno, penggunaan nama "sekolah" pada Sekolah Islam Terpadu menunjukkan bahwa lembaga pendidikan ini secara kelembagaan lebih dekat kepada ciri sekolah umum, bukan madrasah maupun pesantren dan atas dasar pertimbangan pragmatis bahwa selama ini sekolah lebih diminati oleh para peserta didik dari berbagai kalangan di Indonesia daripada madrasah maupun pesantren. Adapun kata "terpadu” digunakan untuk membangun citra Sekolah Islam Terpadu bahwa disamping pengembangan sains dan teknologi, mereka juga mengembangkan pendidikan agama yang excellent. Kata "terpadu" sendiri merupakan simbol adanya kesatupaduan antara pengembangan sains dan teknologi dengan ilmu-ilmu keislaman. (Suyatno,2015:5)

Sementara itu menurut Fuad Muhammad Musa pengertian terpadu lebih pada sistem pendidikan Islam yang diterapakan harus secara utuh, pendidikan islam dijalankan dalam rangka upaya mengembangkan seluruh potensi yang dimiliki manusia, mulai dari potensi keimanan, kepribadian, kebugaran, pikiran, jiwa, kebutuhan secara gender, kebutuhan politik, ekonomi, lingkungan dan sosialnya secara utuh, konperhensif dan berimbang, sebagaimana di utarakannya berikut ini:

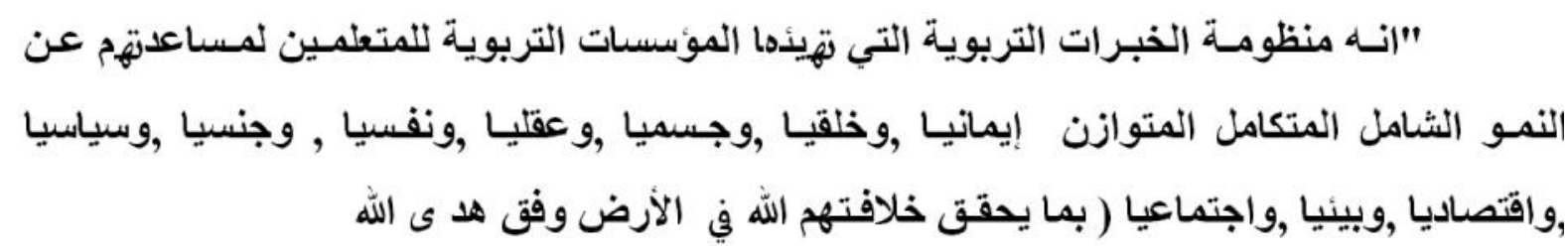

Satu sistem yang memberikan pengalaman-pengalaman pendidikan yang di rancang lembaga pendidikan untuk para peserta didiknya dalam upaya membantu mereka mengembangkan potensi dan bakat yang mereka miliki secara konperhensif,sempurna dan berimbang antara kebutuhan keyakinan, keperibadian, jasmani, akal, jiwa, gender, politik, ekonomi, lingkungan dan sosial dalam upaya mewujudkan rencana ketewakilan mereka sebagai khilafah Allah dimuka bumi ini sesuai petunjuk Allah. (Fuad Muhammad Musa, 2013: 16)

Konsep terpadu ini perlu dibuktikan realisasinya dilapangan dalam konsep pembelajarannya, karena sejauh ini konsep pembelajaran terpadu yang populer di Indonesia dilingkungan akademik hanya ada tiga model. Yaitu ; a. model multidisiplin. b. model antardisiplin. c. model trandisiplin. (Harsono : 2005 : 2). Sedangkan konsep terpadu dalam arti islamisasi ilmu pengetahuan masih sulit di realisasikan.

Kemampuan guru-guru dalam mengimplementasikanya di ruang-ruang kelas perlu dibuktikan, sebab para guru di Indonesia ini dididik seperti konsep terpadu islamisasi tersebut. Islamisasi ilmu seperti konsep al-Faruqi dimaksud lebih pada bahwa setiap disiplin ilmu tak terlepas dari nilai-nilai keagamaan ( tauhid). (Danil M.A : 2014: 190). Maka, yang terpenting dipahami dari konsep terpadu 
tersebut, bahwa semua bentuk disiplin ilmu apa saja harus dapat meningkatkan rasa keimanan peserta didik terhadap Allah SWT, Sang pemberi akal dan ilmu bagi manusia.

Apapun pemaknaan masing-masing sekolah islam terpadu terhadap konsep "terpadu" tersebut menunjukkan bahwa konsep pendidikan Islam terpadu menjadi trend dan kemajuan yang positif bagi sejarah pendidikan Islam di Indonesia. Dengan arti, keragaman pemaknaan dan pemahaman "terpadu" dalam term istilah pendidikan Islam akan memperkaya nuansa sejarah pendidikan Islam di Indonesia, untuk tidak perlu di lakukan standarisasi agar dapat memacu masing-masing lembaga untuk mengembangkan sistem pendidikannya menjadi lebih baik. Biarkanlah masyarakat yang menilai sendiri, karena mereka yang merasakan manfaat dan hasilnya.. Dan yang lebih penting sekolah Islam terpadu telah terlibat memperkaya khazanah sejarah pendidikan Islam di Indonesia.

\section{Sekolah Islam Terpadu Alternatif Pendidikan Islam Di Indonesia}

Islam memandang bahwa ilmu itu sumbernya satu, yaitu berasal dari Tuhan Pencipta manusia dan alam semesta, baik yang bersifat naqliyah maupun yang aqliyah. Jika kita memperhatikan ayat-ayat ilmu dalam al-Quran dan hadits, maka kita akan temukan bahwa kalimat "ilmu" diutarakan bersifat mutlak, tanpa ada embel-embel ilmu agama atau pun ilmu umum, tanpa sekat antara ilmu akhirat dan ilmu dunia. Ungkapan 'ilmu" dalam al-quran dan hadits mencakup semua ilmu yang bermanfaat bagi kemakmuran bumi dan kebaikan hidup manusia, tujuannya agar terlaksana seluruh kewajiban manusia sebagai khilafah di alam semesta ini.(Roghib al-Sarjany, 2007: 10-11)

Oleh sebab itu dalam fakta sejaranya, pada masa keemasan Islam, pendidikan Islam tidak mengenal adanya dikotomi pendidikan. Hanya saja dalam prakteknya, dalam kehidupan masyarakat muslim sejak abad kemunduran Islam terjadi degradasi pemahaman ilmu dikalangan sebagian pemikir intelektual muslim, yang mengakibatkan terjadinya polarisasi antara ilmu-ilmu agama dan ilmu-ilmu umum. Pemikiran ini ternyata juga membawa imbas ke Indonesai, sehingga dalam perkembangannya, lembaga-lembaga pendidikan di Indonesia terbagi pada tiga model, seperti diungkapkan sebelumnya.

Konsep Pendidikan Islam model terpadu sebenarnya tidak membawa konsep baru, sebab konsep sekolah-sekolah Islam terpadu pada dasarnya sudah digagas jauh-jauh hari oleh para pemikir Islam, dimana konsep yang ditawarkan sesungguhnya bagaimana mengoptimalkan segala potensi yang dimiliki manusia secara utuh, tanpa terbelah seperti halanya dalam konsep sekuler, dimana ada pemisahan antara kebutuhan akal, jiwa, qolbu dan jasad. Dalam konsep Islam terpadu keempat aspek yang ada pada diri manusia harus terdidik, terasah, terperhatikan secara optimal.

Untuk lebih jelas, konsep ini bisa di lihat dari gambar yang di buat Tim JSIT Indonesia berikut ini. 


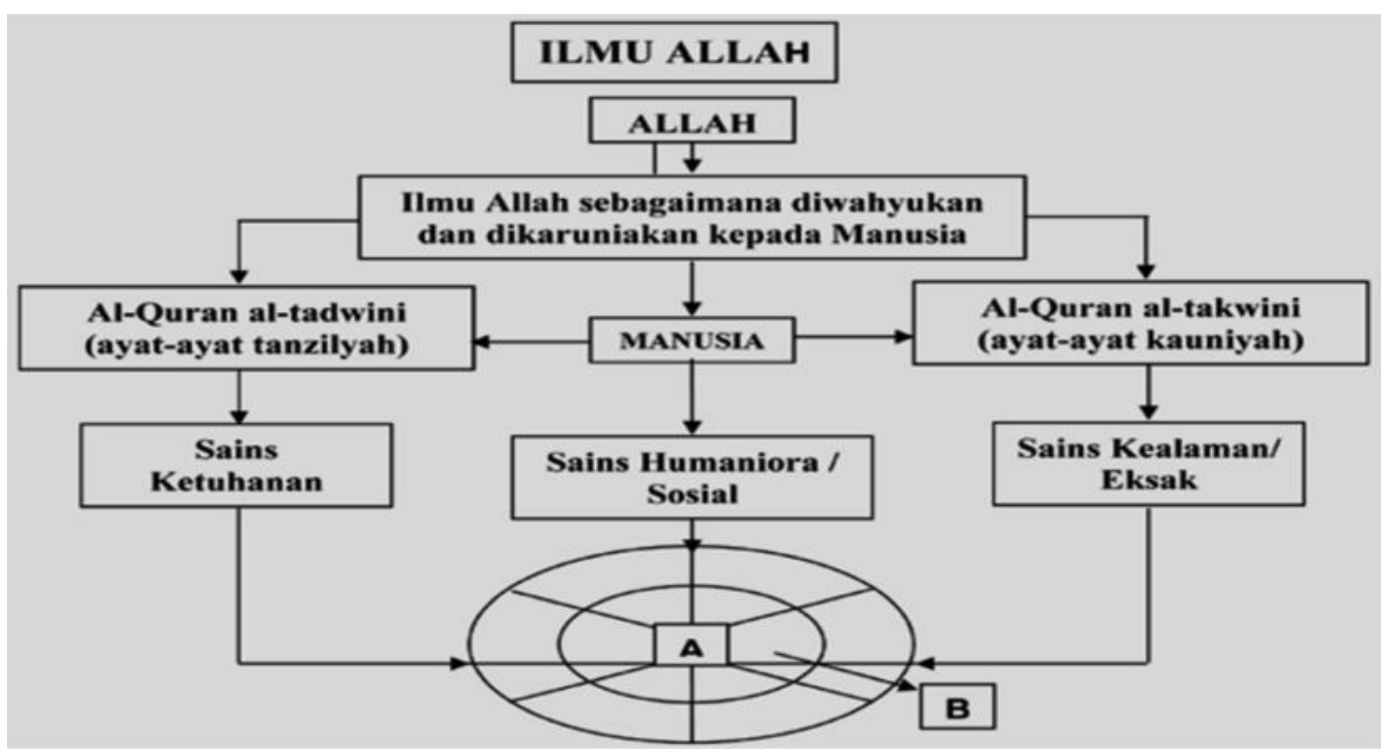

Gambar 1. Filosofis Konsep Sekolah Islam Terpadu.

Gambar Aditengah lingkaran sebagaimana ditunjukkan dalam gambar, merepresentasikan anak didik yang memiliki integrasi antara ketiga keilmuan tersebut, sedangkan gambar B merepresentasikan seseorang yang hanya memiliki penguasaan salah satu dari keilmuan tersebut.(Tim JSIT Indonesia, 2013: 20.

Konsep Sekolah Islam Terpadu tersebut lebih kurang sama dengan apa yang disampaikan Yusuf al-Qordowi. Menurutnya, pendidikan islam itu merupakan pendidikan manusia seutuhnya, akal dan hatinya, rohani dan jasmaninya, akhlak dan keterampilanya. Karena itu ia harus mampu menyiapkan manusia untuk hidup, baik dalam keadaan damai dan perang, menyiapkanya untuk menghadapi masyarakat dengan segala kebaikan dan kejahatanya, manis dan pahitnya.(Yusuf Al-Qordhowi, 1992: 23)

Upaya yang dilakukan Sekolah Islam Terpadu tersebut mencoba meramu kembali konsepkonsep para pemikir Islam terdahulu dengan menajement modern. Jadi, secara konsep, pendidikan islam terpadu merupakan pendidikan Integratif dalam arti "Islamisasi", dimana ilmu pengetahuan di maknai tidak secara terpisah, tidak ada perbedaan perlakuan dan pandangan antara ilmu-ilmu yang bersiaft aqliyah dengan ilmu-ilmu agama, bahkan saling bersinergi, sebab ilmu dalam pandangan islam tidak terpisah-pisah, ilmu itu harus dapat membuat manusia tahu tentang tugas-tugas dan kewajiban, baik sebagai Abdullah ( hamba Allah) maupun sebagai khalifah (pemakmur bumi).

Sekolah Islam Terpadu diharapkan menjadi alternatif-solusitif atas keresahan masyarakat muslim yang menginginkan adanya sebuah institusi pendidikan islam yang berkomitmen mengamalkan nilai-nilai islam, dan mempunyai kompetensi seimbang antara ilmukauniayah dengan ilmu qauliyah, antara fikriyah, ruhiyyah dan jasadiyyah, sehingga mampu melahirkan kembali generasi seperti al-Kindy, al-Biruni, al-Rusydi, dll, meskipun ini terkesan "romantisme" masa lalu.

Banyak kalangan yang berharap bahwa sekolah sekolah islam, apa pun modelnya tidak meninggalkan tiga peran dan fungsi yang diamanatkan padanya,yaitu : 
1. Sebagai tranmisi ilmu-ilmu dan pengetahuan Islam (transmission of knowledge)

2. Sebagai pemelihara tradisi islam (maintenance of Islamic tradition).

3. Sebagai refroduksi calon-calon Ulama ( refroduction of 'ulama). (Marwan Saridjo: 2009)

Ketiga tugas lembaga-lembaga pendidikan islam ini merupakan tujuan berdirinya sekolahsekolah atau lembaga-lembaga pendidikan islam di Indonesia ini.

Tingginya animo masyarakat Muslim Indonesia atas kehadiran sekolah islam terpadu tersebut jangan sampai membawanya terjerembab dalam lingkaran komersialisasi pendidikan yang menitik beratkan pada profit dan keuntungan, tapi kosong dalam kemampuan dan keilmuan. Jangan sampai makna sekolah islam terpadu tersebut dipelestkan menjadi terpaku pada duit.

\section{PENUTUP}

Kehadiran Sekolah Islam Terpadu di Indonesia ini di awal tahun 80-an merupakan kelanjutan dari pembaharuan pendidikan islam di Indonesia. Konsep atau sistem terpadu atau integrasi yang gagas para pendiri sekolah Islam terpadu ini bukanlah pemikiran baru dalam sejarah pendidikan Islam di Indonesia, sebab jauh sebelumnya sudah muncul gagasan yang sama (integrasi) meskipun dengan tanpa slogan terpadu, seperti Adabiyah school, Diniyah School, Diniyah Putri, Normal Islam di Sumatra Barat, Pembaharuan Pendidikan Islam Muhammadiyah di Yogyakarta, Jami'ah al-Khair di Jakarta, Al-Irsayad di Surabaya, dll.

Alasan pembaharuan dalam sejarah pendidikan Islam di Indonesia ini, mulai dari Abdullah Ahmad dengan Adabiyah schoolnya, tahun 1909 sampai Sekolah Islam dengan slogan Terpadunya diawal tahun 80-an, didasarkan atas ketidakpuasan terhadap sistem pendidikann dikotomiknya, disamping ada faktor-faktor lainnya. Akan tetapi, faktor sistem Pendidikan dikotomik- sekuleristik yang menjadi alasan utamanya.

Sekolah Islam Terpadu dengan konsep integrasinya menjadi khazanah bagi sejarah pembaharuan pendidikan islam di indonesia, yang keberadaan perlu diapresiasi dan perlu dicontoh dan dikembangkan demi kemajuan pendidikan islam di indonesia. Keberagaman makna atau intervertasi atas makna terpadu tersebut menunjukkan adanya dinamisasi konsep tersebut dikalangan para pemikir pendidikan Islam di indonesia. Oleh sebab itu tidak perlu dilakukan standarisasi, biarkan masyarakat bebas memilih dan menilai hasil dari lulusan sekolah terpadu tersebut.

Harapannya, sekolah Islam dengan slogan terpadu tersebut menjadi alternatif-solutif atas harapan masyarakat muslim yang merindukan munculnya kembali generasi muslim, semisal al-Kindi, al-Biruni, al-Rusydi, ahli dalam bidang sians, tapi juga memiliki semangat keagaman yang kokoh dan mulia. Jangan sampai Sekolah Islam Terpadu yang telah tersebar diseluruh Indonesia ini masuk pada jurang komersialisasi pendidikan, mahal tapi tak punya kempotensi dan keunggulan, serta tak mencerminkan nilai-nilai Islam yang menjadi simbolnya, yang ujung-ujungnya terpelas menjadi TERpaku Pada Duit. Wallahu 'Alam. 


\section{DAFTAR PUSTAKA}

Al-Kilani, Majid Irsan. 1987. Falsafah al-Tarbiyah al-Islāmiyyah : Dirāsah Muqāranah baina F alsafah al-Tarbiyah al-Islāmiyyah wa al-F alsafāt al-Tarbawiyyah al-M u'āshirah,Cet. ke1. Mekkah: Maktabah al-Manārah. 1998. Ahdāf al-Tarbiyah al-Islāmiyyah fi Tarbiyah al-F ard wa Ikhrāj al-U mmah wa Tanmiyah al-U khuwwah al-Insāniyyah,Cet. Ke-2. Virginia: The International Institute of Islamic Thought .

Al-Qardhawi,Yusuf. 2006. Islam dan Sekularisme diterjemahkan dari buku: Al-Islam wal IIma'niyah wajhan lil wajhin. Cet.I. Bandung:Pustaka Setia.

1992. At-Tarbiyah al-Islāmiyyah wa M adrasatu Hasan al-Bannā. .Kairo: MaktabahWahbah.

Al-Sarjany, Roghib. 2007. Al-IImu wa Biana al-U mam, dirasah ta'shilyah li daur al 'ilmi fi binai al daulah. Al-Qohirah: Muassasah Iqra'.

Danil, M.A. 2014. Filsafat Ilmu. Yogyakarta ; Kaukaba.

Harsono, dkk. 2005. Kurikulum Terpadu. Yogyakarta : Pusat Pengembangan Pendidikan UGM.

Hamalik, Oemar. 2001.Pendekatan Baru Srategi Belajar Mengajar Berdasarkan CBSA. Bandung: Sinar Baru.

Kurnianengsih. 2015. “Konsep Sekolah Islam Terpadu (kajian pengembangan lembaga pendidikan islam di indonesia" dalam jurnal 'Risalah' Pendidikan dan Studi Islam. Fakultas Agama Islam Wiralodra. Indramayu. Vol.1 Desember 2015.

Kundjoro. 1991. Metode Penelitian Masyarakat. Jakarta : PT Gramedia.

Moedliono, Imam. 2002. "Konsep Dan Implementasi Pendidikan Islam Terpadu" dalam Jurnal Pendidikan Islam. Jurusan Tarbiyah. Volume VII Tahun V Juni 2002.

Musa, Fuad Muhammad. 2013. Al-Asasul Al-Islamiyah Li Tarbiyah Abnai Al-Ummah, (Al-Manshurah : Syuruq Li Tarjamah wa an-Nasry.

Nata, Abuddin. 2012. Ilmu Pendidikan Islam. Jakarta: Kencana.

. 2015. "Pendidikan Agama Islam di Sekolah, dalam Article November 2015, di akses dari https://www.researchgate.net/publication/296443701. Pada tanggal 10 Agustus 2018. Pukul 09.45 WIB.

Ramayulis. 2012. Sejarah Pendidikan Islam, Napak Tilas Perubahan Konsep, Filsafat, Dan Metodologi Pendidikan Islam Dari Era Nabi SAW Sampai Ulama Nusantara. Jakarta; Radar Jaya Ofset.

Saridjo, Marwan. 2009. (Penyun), Mereka Bicara Pendidikan Islam: Sebuah Bungan Rampai. Jakarta: RajaGrapindo Persada.

Seabahar, Abd. Halim. 2013. Kebijakan Pendidikan Islam Dari Ordonansi Guru Sampai UUD Sisdiknas. Jakarta : Raja Grapindo Persada.

Steenbrink, Karel A. 1986. Pesantren, Madrasah, Sekolah. Jakarta: LP3ES The Columbia Encyclopedia ,1963. NY \& London: Colombia University Press.

Soemantri, Muhammad Numan. 2001. Menggagas Pembaharuan Pendidikan IPS. Bandung: PT. Remaja Rosda Karya.

Sugiyono. 2016. Metode Penelitian Pendidikan. Bandung: Alfabeta.

Suyatno. 2015. "Sekolah Islam Terpadu Dalam Sistem Pendidikan Nasional" dalam Jurnal "Al-Qalam" . UIN Sunan Kalijaga. Yogyakarta. Volume 21 Nomor 1 Juni 2015.

. 2013. "Sekolah Islam Terpadu; Filsafat, Ideologi, dan Tren Baru Pendidikan Islam di Indonesia" dalam Jurnal Pendidikan Islam. Universitas Ahmad Dahlan. Yogyakarta. Volume II. Nomor 2 Desember 2013. 
Tim Mutu JSIT Indonesia. 2014. Standar Mutu Kekhasan Sekolah Islam Terpadu, Jakarta: t.p.

Tim JSIT Indonesia. 2013. Membangun Pendidikan Bermutu Melalui Sekolah Islam Terpadu, Jakarta: t.p

Yusuf, Zainab Basyarah. 1431. Min asaaliib al-Tarbiya fi al-Quran al-Karim, dalam Tesisnya meraih gelar Magister dalam bidang Tafsir dan Ulum al-Quran. Universitas Internasional Madinah. 